\title{
Cryptococcus mujuensis sp. nov. and Cryptococcus cuniculi sp. nov., basidiomycetous yeasts isolated from wild rabbit faeces
}

\author{
Kee-Sun Shin, ${ }^{1}$ Hee-Mock Oh, ${ }^{1}$ Yong-Ha Park, ${ }^{1}$ Kang Hyun Lee, ${ }^{1}$ \\ Haryoung Poo, ${ }^{2}$ Gi-Seok Kwon ${ }^{3}$ and O-Yu Kwon ${ }^{4}$ \\ 1,2Biological Resource Center ${ }^{1}$ and Proteome Research Laboratory ${ }^{2}$, Korea Research Institute \\ of Bioscience and Biotechnology, Yusong, Daejon 305-333, Republic of Korea \\ ${ }^{3}$ The School of Bioresource Science, Andong National University, Andong 760-749, Republic \\ of Korea \\ ${ }^{4}$ Department of Anatomy, School of Medicine, Chungnam National University, Daejon 301- \\ 131, Republic of Korea
}

Correspondence

Kee-Sun Shin

ksshin@kribb.re.kr

\begin{abstract}
Two previously undescribed anamorphic yeasts, strains $T-11^{\top}$ and $T-26^{\top}$, recovered from wild rabbit faecal pellets collected in Muju, Korea, were identified using phenotypic and molecular taxonomic methods. The isolates were characterized by the proliferation of budding cells, positive diazonium blue $\mathrm{B}$ and urease reactions, the presence of $\mathrm{Q}-10$ as the major ubiquinone, the presence of xylose in whole-cell hydrolysates and the inability to ferment sugars. Phylogenetic analyses based on $26 \mathrm{~S}$ rRNA gene partial sequences revealed that strain $\mathrm{T}-11^{\top}$ was located in the Bulleromyces clade and was related to Sirobasidium intermedium, Tremella exigua, Cryptococcus cellulolyticus and Bullera pseudoalba. Strain T-26 ${ }^{\top}$ was located in the Mesenterica clade and was closely related to Cryptococcus sp. F6 and Cryptococcus heveanensis CBS 8976. Sequence divergence values of more than $4 \%$ from other described Cryptococcus species, together with the phenotypic differences, showed that the isolated yeasts represent previously unrecognized members of this genus. Therefore, two novel yeast species are proposed: Cryptococcus mujuensis sp. nov., with strain $\mathrm{T}-11^{\top}\left(=\mathrm{KCTC} 17231^{\top}=\mathrm{CBS} 10308^{\top}\right)$ as the type strain, and Cryptococcus cuniculi sp. nov., with strain T-26 ${ }^{\top}\left(=\right.$ KCTC $17232^{\top}=$ CBS $\left.10309^{\top}\right)$ as the type strain.
\end{abstract}

Probiotics have been defined as live microbial food supplements that affect the host beneficially by improving the intestinal microbial balance or 'living micro-organisms that, upon ingestion in certain numbers, exert health benefits beyond inherent basic nutrition' (Guarner \& Schaafsma, 1998). While screening wild rabbit faeces for probiotic yeasts for consumption by farm animals, a number of yeast strains were isolated, two of which exhibited very low genetic relatedness to any previously described species of the genus Cryptococcus. Accordingly, this paper describes the phenotypic, biochemical and genotypic characterizations of these novel strains and, based on a comparative analysis with other related species, it is proposed that they represent two novel species in the genus Cryptococcus Vuillemin.

Strains $\mathrm{T}-11^{\mathrm{T}}$ and $\mathrm{T}-26^{\mathrm{T}}$ were isolated from faecal pellets left by wild rabbits on a hill in Muju, Korea in 2002. One gram of

The GenBank/EMBL/DDBJ accession numbers for the 26S rRNA gene D1/D2 domain sequences of strains $T-11^{\top}$ and $T-26^{\top}$ are D0333884 and DQ333885, respectively. each sample was suspended in $9 \mathrm{ml}$ sterile water and stirred for $10 \mathrm{~min}$. The yeasts were isolated after picking from plates of YM agar (Difco) supplemented with $5 \mu \mathrm{g}$ gentamicin $\mathrm{ml}^{-1}$ and $16 \mu \mathrm{g}$ chloramphenicol $\mathrm{ml}^{-1}$ spread with a suitable diluted suspension from the samples. The strains were then purified by streaking an isolated colony onto YM agar without antibiotics and incubating at $25^{\circ} \mathrm{C}$. Thereafter, the strains were maintained at $4^{\circ} \mathrm{C}$. Cell suspensions were stored at $-80^{\circ} \mathrm{C}$ in broth cultures supplemented with $10 \%(\mathrm{w} / \mathrm{v})$ glycerol for long-term preservation.

Phenotypic tests were performed in duplicate using the standard protocols described by Yarrow (1998). Utilization of carbon and nitrogen sources in liquid yeast nitrogen base (Difco) and yeast carbon base (Difco) was examined at $25^{\circ} \mathrm{C}$ on a rotary shaker rotating at a speed of 100 r.p.m., whereas growth at different temperatures was determined on YM agar. The extraction and purification of ubiquinones was carried out according to Yamada \& Kondo (1973) and ubiquinone isoprenologues were identified by reverse-phase TLC (HPTLC RP-18 F254; Merck), based on comparing 
their $R_{\mathrm{F}}$ values with those of standard ubiquinones. Xylose in the cells was investigated by TLC analysis, as reported by Komagata \& Suzuki (1987). Genomic DNA isolation and PCR amplification of the D1/D2 region of the 26S rRNA gene was performed using protocols described by Fell et al. (2000). Amplified fragments were purified using a QIAquick PCR purification kit (Qiagen) and directly sequenced using an ABI Taq Dye Deoxy Terminator cycle sequencing kit and ABI 310 DNA sequencer (Applied Biosystems). The resultant sequences were automatically aligned using the multiple-sequence alignment program CLUSTAL $\mathrm{X}$ (Thompson et al., 1997) and subsequently manually corrected. Phylogenetic relationships were then calculated using the program package PHYLIP 3.57c (Felsenstein, 1995), a distance matrix was obtained using the program DNADIST and an unrooted phylogenetic tree was constructed using neighbour-joining (Saitou \& Nei, 1987) and the program NEIGHBOR. Bootstrap values (Felsenstein, 1985) were calculated from 1000 replicates; Tremella encephala CBS 6968 (AF189867) was the designated outgroup in the analysis and other related sequences were obtained from GenBank.

Eight faecal pellets were collected in one sampling in March 2002. A total of 49 yeast isolates was obtained from the wild rabbit faecal samples. The temperatures of the faecal samples ranged from 15 to $18{ }^{\circ} \mathrm{C}$. The 49 isolates could be distinguished by molecular means based on sequences of the D1/ D2 domain of the 26S rRNA gene. Most of the strains present in the samples revealed a basidiomycetous affinity and were identified as Cryptococcus victoriae $(n=25)$, Bullera armeniaca $(n=1)$, Rhodotorula pinicola $(n=1)$ and Cryptococcus species $(n=15)$. The others were identified as Wallrothiella subiculosa $(n=7)$. Two of the yeast isolates, $\mathrm{T}-11^{\mathrm{T}}$ and $\mathrm{T}-26^{\mathrm{T}}$, were selected for further analysis on the basis of their 26S rRNA gene D1/D2 nucleotide sequences, which were very different and displayed $4 \%$ or greater sequence divergence from established species in comparative $26 \mathrm{~S}$ rRNA gene partial sequencing. A tree constructed by the neighbour-joining method and depicting the phylogenetic position of these unknown yeasts among Tremellales from Hymenomycetes is shown in Fig. 1 . Strain $\mathrm{T}-11^{\mathrm{T}}$ was found in the Bulleromyces clade of Tremellales and its closest phylogenetic relatives were Sirobasidium intermedium CBS 7805 ( $95 \cdot 8 \%$ similarity; differed by 24 nt substitutions and 2 nt indels), Tremella exigua RB 6623-15 (95·1\% similarity; differed by $28 \mathrm{nt}$ substitutions and $5 \mathrm{nt}$ indels), Cryptococcus cellulolyticus CBS $8294^{\mathrm{T}}$ and Bullera pseudoalba CBS $7227^{\mathrm{T}}$, which both differed by $23 \mathrm{nt}(96 \cdot 0 \%)$. Strain T-26 ${ }^{\mathrm{T}}$ grouped with Cryptococcus sp. F6 (96.7\% sequence similarity; $19 \mathrm{nt}$ differences) and Cryptococcus heveanensis CBS 8976 (96.0\% similarity; 23 nt differences). C. heveanensis CBS $569^{\mathrm{T}}$ was also related to strain $\mathrm{T}-26^{\mathrm{T}}$, with a sequence similarity of $94 \cdot 1 \%$ (34 nt differences).

The two novel strains were characterized by their lack of ballistoconidia, the presence of xylose in cell hydrolysates and the presence of $\mathrm{Q}-10$ as the major ubiquinone. No sexual states were observed in $\mathrm{T}-11^{\mathrm{T}}$ and $\mathrm{T}-26^{\mathrm{T}}$ cultures on

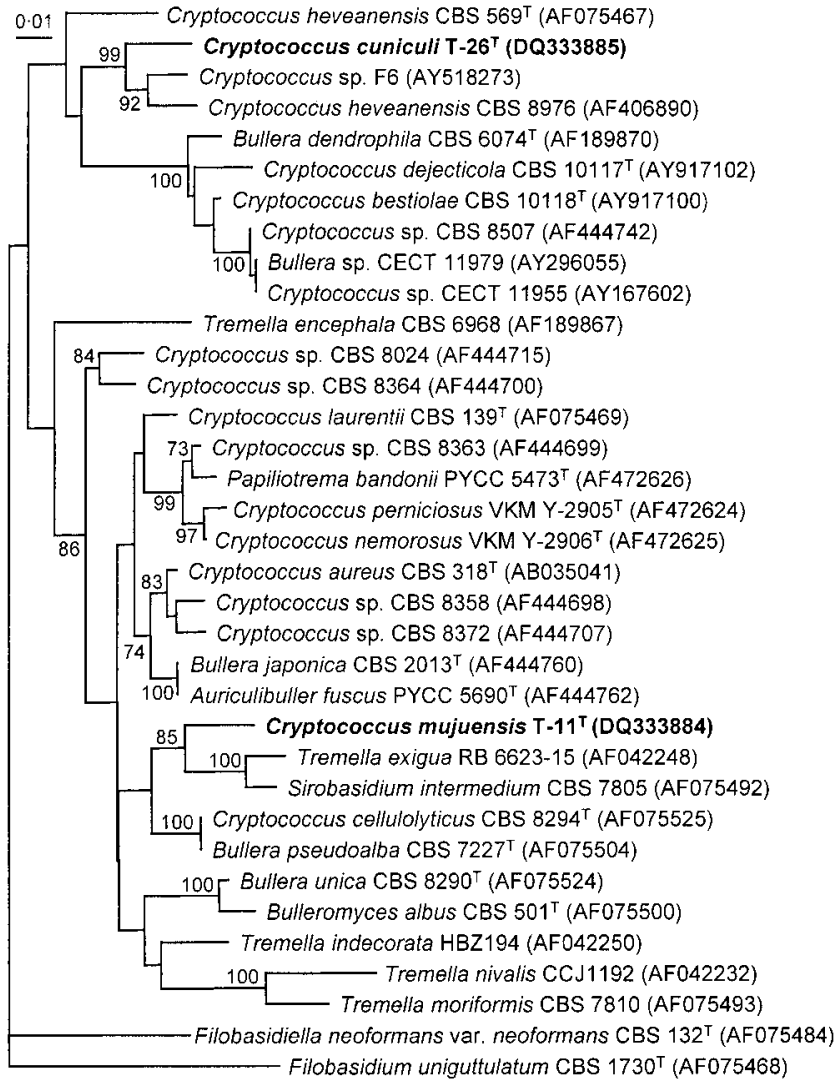

Fig. 1. Neighbour-joining tree based on D1/D2 divergent domains of large-subunit rRNA gene sequences of Cryptococcus mujuensis sp. nov. $\mathrm{T}-11^{\top}$, Cryptococcus cuniculi sp. nov. $\mathrm{T}-26^{\mathrm{T}}$ and their closest relatives. Bootstrap values (\%) above $70 \%$ from 1000 samples are shown. Accession numbers are given in parentheses. Bar, $0.01 \mathrm{nt}$ substitutions per site. The outgroup sequences were from Filobasidiella neoformans var. neoformans CBS $132^{\top}$ (AF075484) and Filobasidium uniguttulatum CBS $1730^{\top}$ (AF075468).

cornmeal agar and $5 \%$ malt extract. Although their phenotypic and chemotaxonomic characteristics were consistent with those of members of the genus Cryptococcus (Fell \& Statzell-Tallman, 1998), the isolates could be differentiated phenotypically from other Cryptococcus species described to date. Strain T- $11^{\mathrm{T}}$ differed from C. cellulolyticus CBS $8294^{\mathrm{T}}$ in its assimilation of erythritol, growth in the presence of $0.01 \%$ cycloheximide and very weak growth at $30^{\circ} \mathrm{C}$. It also differed from B. pseudoalba CBS $7227^{\mathrm{T}}$ in its ability to utilize erythritol, to grow weakly at $30^{\circ} \mathrm{C}$ and to produce starch-like substances, and its inability to utilize D-glucarate and to grow in the presence of $0 \cdot 1 \%$ cycloheximide.

Strain $\mathrm{T}-26^{\mathrm{T}}$ could be distinguished from C. heveanensis CBS $569^{\mathrm{T}}$ based on its inability to grow on methyl $\alpha$-D-glucoside, raffinose, inulin, erythritol, DL-lactate, quinic acid and $50 \%(\mathrm{w} / \mathrm{v})$ glucose and its ability to grow at $30^{\circ} \mathrm{C}$, on glycerol and D-tryptophan and in the presence of $0.01 \%$ cycloheximide. It also differed from Bullera 
dendrophila CBS $6074^{\mathrm{T}}$ in its inability to assimilate methyl $\alpha$ D-glucoside and DL-lactate and to grow in $50 \%(\mathrm{w} / \mathrm{v})$ glucose and its ability to assimilate L-sorbose, cadaverine and D-tryptophan and to grow in $10 \%(\mathrm{w} / \mathrm{v}) \mathrm{NaCl}$ and $0 \cdot 01 \%$ cycloheximide.

Results of the polyphasic taxonomic analysis clearly showed that the yeasts isolated from the faecal pellets of wild rabbits represented hitherto unrecognized species within the genus Cryptococcus. Thus, based on the phenotypic and molecular data presented above, it is proposed that strains $\mathrm{T}-11^{\mathrm{T}}$ and $\mathrm{T}-26^{\mathrm{T}}$ be classified as representatives of novel species within the genus Cryptococcus: Cryptococcus mujuensis (type strain $\left.\mathrm{T}-11^{\mathrm{T}}=\mathrm{KCTC} 17231^{\mathrm{T}}=\mathrm{CBS} 10308^{\mathrm{T}}\right)$ and Cryptococcus cuniculi $\left(\right.$ type strain T-26 ${ }^{\mathrm{T}}=$ KCTC $17232^{\mathrm{T}}=\mathrm{CBS} 10309^{\mathrm{T}}$ ).

\section{Latin diagnosis of Cryptococcus mujuensis Shin et Park sp. nov.}

In agaro YM post dies 3 ad $25^{\circ} \mathrm{C}$ cellulae ovoideae aut ellipsoideae $(2 \cdot 8-5 \cdot 4 \times 2 \cdot 1-4 \cdot 0 \mu \mathrm{m})$, singulae, aut binae, per germinationem multipolarem reproducentes. In $\mathrm{YM}$ (Difco) liquido post unum mensem ad $20^{\circ} \mathrm{C}$, pellicula et sedimentum formantur. Cultura pallida, albida vel cremea, glabra, nitida, butyrosa et margine glabra. Assimilantur Dglucosum, D-galactosum, D-glucosaminum, D-ribosum, Dxylosum, L-arabinosum, D-arabinosum, L-rhamnosum, sucrosum, maltosum, trehalosum, methyl $\alpha$-D-glucosidum, cellobiosum, salicinum, arbutinum, melibiosum (lente), lactosum, raffinosum, melezitosum, amylum solubile, glycerolum (lente), erythritolum, ribitolum, xylitolum, Larabitolum, D-glucitolum, D-mannitolum, galactitolum,

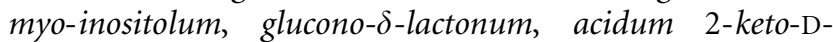
gluconicum, acidum 5-keto-D-gluconicum, acidum gluconicum, acidum glucuronicum, acidum galacturonicum, acidum DL-lacticum (lente, infirme) et acidum succinicum. Non assimilantur L-sorbosum, inulinum, methanolum, propane1,2-diolum, butane-2,3-diolum, acidum quini et acidum saccharicum. Assimilantur ethylaminum, L-lysinum (lente), cadaverinum et glucosaminum. Non assimilantur kallii nitratum, sodii nitritum, creatinum, creatininum, imidazolum et D-tryptophan. Vitaminae externae ad crescentiam necessaria sunt. Crescit in $0.01 \%$ cycloheximido et $10 \%$ $\mathrm{NaCl} / 5 \%$ glucosum. Non crescit in $50 \%$ glucosum, $0 \cdot 1 \%$ cycloheximido et $16 \% \mathrm{NaCl} / 5 \%$ glucosum. Urea finditur. Diazonium caeruleum B positivum. Materia amyloidea iodophila formantur. Crescit in $30^{\circ} \mathrm{C}$; non crescit in $35^{\circ} \mathrm{C}$. Ubiquinonum majus: Q-10. Typus depositus in collectione Korean Collection for Type Cultures $\left(\mathrm{T}-11^{\mathrm{T}}\right)$.

\section{Description of Cryptococcus mujuensis Shin \& Park sp. nov.}

Cryptococcus mujuensis (mu.ju.en'sis. N.L. masc. adj. mujuensis of Muju, referring to the name of the region where the type strain was isolated).

After growth on YM agar for 3 days at $25^{\circ} \mathrm{C}$, cells are ovoid to ellipsoid $(2 \cdot 8-5 \cdot 4 \times 2 \cdot 1-4 \cdot 0 \mu \mathrm{m})$ and occur singly or in pairs. Budding is multilateral. In YM broth, after 1 month at $20^{\circ} \mathrm{C}$, sediment and a pellicle are present. Streak culture is pale, white to cream, smooth, glistening and butyrous, with an entire margin. D-Glucose, galactose, D-glucosamine, D-ribose, D-xylose, L-arabinose, D-arabinose, L-rhamnose, sucrose, maltose, trehalose, methyl $\alpha$-D-glucoside, cellobiose, salicin, arbutin, melibiose (delayed), lactose, raffinose, melezitose, soluble starch, glycerol (delayed), erythritol, ribitol, xylitol, L-arabitol, D-glucitol, D-mannitol, galactitol, myo-inositol, glucono- $\delta$-lactone, 2-ketogluconic acid, 5-ketogluconic acid, D-gluconate, D-glucuronate, Dgalacturonic acid, DL-lactate (delayed, weak) and succinic acid are assimilated. L-Sorbose, inulin, methanol, propane1,2-diol, butane-2,3-diol, quinic acid and saccharate are not assimilated. Ethylamine hydrochloride, L-lysine (delayed), cadaverine and glucosamine are assimilated. Potassium nitrate, sodium nitrite, creatine, creatinine, imidazole and D-tryptophan are not assimilated. Does not grow in vitamin-free medium. Grows in $0.01 \%$ cycloheximide and $10 \% \mathrm{NaCl} / 5 \%$ glucose. Does not grow in $50 \%$ glucose, $0 \cdot 1 \%$ cycloheximide and $16 \% \mathrm{NaCl} / 5 \%$ glucose. Positive for urease activity and diazonium blue $\mathrm{B}$ reaction. Produces starch-like compounds. Grows (very weakly) at $30^{\circ} \mathrm{C}$, but does not grow at $35^{\circ} \mathrm{C}$. The major ubiquinone is $\mathrm{Q}-10$.

The type strain is $\mathrm{T}-11^{\mathrm{T}}\left(=\mathrm{KCTC} 17231^{\mathrm{T}}=\mathrm{CBS} 10308^{\mathrm{T}}\right)$, isolated from wild rabbit faecal samples collected on a hill in Muju, Korea.

\section{Latin diagnosis of Cryptococcus cuniculi Shin et Park sp. nov.}

In agaro YM post dies 3 ad $25^{\circ} \mathrm{C}$, cellulae sphaeroidae, ovoideae aut ellipsoideae, $2 \cdot 1-5 \cdot 8 \times 1 \cdot 8-5 \cdot 0 \mu \mathrm{m}$, singulae vel binae; gemmatione bipolari repruducentes. Cultura cremae aut xanthoalba, glabra, nitida, butyrosa et margine glabra. In medio liquido YM post unum mensem ad $20^{\circ} \mathrm{C}$, annulus tenuis et sedimentum formantur. In agaro farina Zeae maydis confecto pseudomycelium rudimentarium. D-Glucosum, Dgalactosum, L-sorbosum (lente), D-ribosum, D-xylosum, Larabinosum, D-arabinosum, L-rhamnosum, sucrosum, maltosum, trehalosum, cellobiosum, arbutinum, lactosum, melezitosum, amylum solubile, glycerolum (lente), xylitolum, L-arabitolum (lente), D-glucitolum, D-mannitolum, galactitolum, myo-inositolum, glucono- $\delta$-lactonum, acidum 2keto-D-gluconicum, acidum 5-keto-D-gluconicum, acidum gluconicum, acidum glucuronicum, acidum galacturonicum, acidum succinicum, ethanolum, acidum saccharicum assimilantur, at non D-glucosaminum, methyl $\alpha$-D-glucosidum, melibiosum, raffinosum, inulinum, erythritolum, acidum DL-lacticum, methanolum, propane-1,2-diolum, butane-2,3diolum nec acidum quini. Ethylaminum, L-lysinum, cadaverinum et D-tryptophanum (lente) assimilantur, at non kallii nitratum, sodii nitritum, creatinum, creatininum, glucosaminum nec imidazolum. Vitaminae externae ad crescentiam necessaria sunt. Diazonium caeruleum B positivum. Urea finditur. In medio cum $50 \%$ glucose crescit. Amyli instar 
composite creantur. Crescit in $30^{\circ} \mathrm{C}$; non crescit in $35^{\circ} \mathrm{C}$. Systema coenzymatis Q-10 adest. Typus depositus in collectione Korean Collection for Type Cultures $\left(\mathrm{T}-26^{\mathrm{T}}\right)$.

\section{Description of Cryptococcus cuniculi Shin \& Park sp. nov.}

Cryptococcus cuniculi (cu'ni.cu.li. L. gen. n. cuniculi of a rabbit, referring to the animal from faecal pellets of which the type strain was isolated).

After growth on YM agar for 3 days at $25^{\circ} \mathrm{C}$, cells are spherical, ovoid to ellipsoidal, $2 \cdot 1-5 \cdot 8 \times 1 \cdot 8-5 \cdot 0 \mu \mathrm{m}$, single or in pairs. Budding is bipolar. Streak culture is cream to yellowish-white, smooth, glistening and butyrous, with an entire margin. In YM broth after 1 month at $20^{\circ} \mathrm{C}$, sediment and a ring are formed. In Dalmau plate cultures on cornmeal agar after 2 weeks, no hyphae or pseudohyphae are formed. The following carbon compounds are assimilated: Dglucose, galactose, L-sorbose (delayed), D-ribose, D-xylose, L-arabinose, D-arabinose, L-rhamnose, sucrose, maltose, trehalose, cellobiose, arbutin, lactose, melezitose, soluble starch, glycerol (delayed), xylitol, L-arabitol, D-glucitol, D-mannitol, galactitol, myo-inositol, glucono- $\delta$-lactone, 2-ketogluconic acid, 5-ketogluconic acid, D-gluconate, D-glucuronate, D-galacturonic acid, succinic acid, ethanol and saccharate. No growth occurs on D-glucosamine, methyl $\alpha$-D-glucoside, melibiose, raffinose, inulin, erythritol, DL-lactate, methanol, propane-1,2-diol, butane-2,3-diol or quinic acid. Does not assimilate potassium nitrate, sodium nitrite, creatine, creatinine, glucosamine or imidazole. Assimilates ethylamine hydrochloride, L-lysine, cadaverine and D-tryptophan (delayed). Does not grow in vitamin-free medium. Growth in the presence of $10 \%$ $\mathrm{NaCl} / 5 \%$ glucose is delayed and weak. Positive for the diazonium blue B reaction and urease activity. Growth in the presence of $0.01 \%$ cycloheximide is delayed and positive. Does not grow on $50 \%(\mathrm{w} / \mathrm{w})$ glucose/yeast extract agar. Produces starch-like compounds. Grows at $30^{\circ} \mathrm{C}$ (very weak), but not at $35^{\circ} \mathrm{C}$ on YM agar. The ubiquinone type is Q-10.
The type strain is $\mathrm{T}-26^{\mathrm{T}}\left(=\mathrm{KCTC} 17232^{\mathrm{T}}=\mathrm{CBS} 10309^{\mathrm{T}}\right)$, isolated from rabbit faecal samples collected on a hill in Muju, Korea.

\section{Acknowledgements}

This research was supported by a grant from the KRIBB Research Initiative Program and grant BDM0200524 from the Korean Ministry of Science and Technology (MOST).

\section{References}

Fell, J. W. \& Statzell-Tallman, A. (1998). Cryptococcus Vuillemin. In The Yeasts, a Taxonomic Study, 4th edn, pp. 742-767. Edited by C. P. Kurtzman \& J. W. Fell. Amsterdam: Elsevier.

Fell, J. W., Boekhout, T., Fonseca, A., Scorzetti, G. \& StatzellTallman, A. (2000). Biodiversity and systematics of basidiomycetous yeasts as determined by large-subunit rDNA D1/D2 domain sequence analysis. Int J Syst Evol Microbiol 50, 1351-1371.

Felsenstein, J. (1985). Confidence limits on phylogenies: an approach using the bootstrap. Evolution 39, 783-791.

Felsenstein, J. (1995). PHYLIP (phylogeny inference package), version 3.57c. Distributed by the author. Department of Genome Sciences, University of Washington, Seattle, USA.

Guarner, F. \& Schaafsma, G. J. (1998). Probiotics. Int J Food Microbiol 39, 237-238.

Komagata, K. \& Suzuki, K. (1987). Lipid and cell-wall analysis in bacterial systematics. Methods Microbiol 19, 161-206.

Saitou, N. \& Nei, M. (1987). The neighbor-joining method: a new method for reconstructing phylogenetic trees. Mol Biol Evol 4, 406-425.

Thompson, J. D., Gibson, T. J., Plewniak, F., Jeanmougin, F. \& Higgins, D. G. (1997). The CLUSTAL_X windows interface: flexible strategies for multiple sequence alignment aided by quality analysis tools. Nucleic Acids Res 25, 4876-4882.

Yamada, Y. \& Kondo, K. (1973). Coenzyme Q system in the classification of the yeast genera Rhodotorula and Cryptococcus, and the yeast-like genera Sporobolomyces and Rhodosporidium. J Gen Appl Microbiol 19, 59-77.

Yarrow, D. (1998). Methods for the isolation, maintenance and identification of yeasts. In The Yeasts, a Taxonomic Study, 4th edn, pp. 77-100. Edited by C. P. Kurtzman \& J. W. Fell. Amsterdam: Elsevier. 